\title{
Coming out of a deep hole after a life of trials
}

\section{Charlotte Uwera}

My name is Charlotte Uwera. I was born in 1969. I studied until primary six. My father was a mason and my mother a cultivator. I am one of six siblings. Three of my siblings died during the genocide and the fourth one faced a normal death. Only my big sister and I survived the genocide. I have nine children of my own and three adopted children. Among those nine children, there is one daughter born as a result of gang rape. Before the genocide happened, I had six children with my non-legal husband. We had been living together since 1987. I lost two of my children during the genocide and gave birth to my other four children from my husband after the genocide. Before the genocide, I was living a good life. I had no problems because I still had my relatives. The person I loved most was my mother, because when I had any problems we solved them together. In my daily life, I miss my peers who were such good friends.

When the 1994 genocide started, I survived it because of God. The Interahamwe cut me a number of times with their machetes, stepped on my belly, and left me where I had taken refuge. They cut me after I had become tired of running. I ran away just to reach anywhere else; I was searching for refuge. I was in Nyamata Catholic parish, I went to Ntarama Catholic Church, and I met the killers wherever I went. When I was in Ntarama Church, I saw that it would be very difficult to escape from there. Then I ran away towards the nearby swamp. They caught me there and cut both my legs. I stayed there lying on my back because I could not move. They came and cut me with their machetes and set up a fire with dry banana leaves, but I did not die. My husband was hiding nearby and he was the one who gave me water and poured water on my wounds, especially during the night. That is why the Inkotanyi, after capturing Nyamata, found me while I was still breathing.

I have been deprived of my human rights. They killed my relatives in front of my eyes. They cut me everywhere, and then a group of more than one hundred men came to rape me. It was very hard to live in the swamp full of water, being bitten by mosquitoes, without anything to eat and without any place to be treated. There was no one to take care of us. What was most upsetting was lacking something to feed my children.

During the genocide, I was impregnated by the rapists while I had twins of three months old. Firstly, I was raped by five men. That rape happened to me two times when I was still conscious. The second time, it was a crowd composed of Burundians, Rwandese and soldiers. All of these men raped me in an open place. My children and three cousins I still take care of today know what happened to me. They saw me as naked as the way I was when I was created by God, even if they are still young. This causes me deep shame; I have been unimaginably robbed of value.

I know some of the rapists. Among those who abused me, I recognized one. $\mathrm{He}$ recently died of AIDS. When I called them by their names while they were beating me, they told me, "This is the end of your time, your mandate has finished, you have to die, 
and you have to be used however we want." I and the other women who had been raped in this swamp thought that after they raped us, they would kill us, but they did not.

When I try to measure all of the bad experiences I faced during the genocide, I conclude that being deprived of one's value as a human being, and being raped in a public place in front of many people, was the most traumatizing. After the rape, I did not feel like a human being as others do. I thought that I do not have a word anywhere in the world; I was ashamed. After leaving the swamp, the Inkotanyi dropped me at the hospital. I passed approximately one year there. When I was in the hospital, my husband stayed around me and took good care of me. After the genocide, however, all people stigmatized me. They were always saying that we (female genocide survivors) must have become wives of the Interahamwe. We were also considered to be mad persons; for instance they said that the Interahamwe had injected me with troubles and madness.

When the genocide was over, I presumed that my husband did not know that I had been raped. After regaining consciousness, I felt that I did not need him because I no longer had desire for any man. When I revealed to him that I had been raped, he did not reject me. He told me that he knew more about what had happened to me than I did. He did not stigmatize me, but his family rejected me. His mother considers me to be a wicked person, as if I had called on the men to rape me. I do not have a family except for my oldest sister, whom I found after the end of the genocide. She did not stigmatize me. Seeing many people being killed inside the Catholic Church was the reason I changed my religion. I am no longer Catholic, I became Pentecostal.

I did not expect that I would still be breathing until now. I have no income. When
I get a chance to be invited to any training, I go and participate. I manage to survive with the money they give me for transport until I earn some more money somehow. I have participated in training about counselling and family planning. I was trained with community health workers. After this training, World Vision/New Hope trained us about HIV prevention, making a kitchen garden and preparing a balanced diet. In addition, I have been trained by Kanyarwanda about trauma counselling. Kanyarwanda also helped me to get treatment for the gynaecological problems I have suffered from since the genocide. FARG pays mutual health insurance for me and my children born before the genocide. It is also paying the school fees for those children. I do receive direct support as other vulnerable people do, but it is not enough given the size of the family I have to feed.

Because of what happened to me during the genocide, afterwards I had no life. I was always ill. Out of seven days, I am only healthy two days. I suffer from poverty and physical problems. My reproductive health parts have been wounded. After they cut me with the machetes on my head, I was in a coma, which damaged my brain. When something made me sad, I felt like I was not thinking. I froze or I would fall down like someone who has epilepsy. Sometimes my wounds become fresh without me knowing why. I experienced severe ihahamuka and I had flashbacks, especially during the night.

In 2006, I benefited from group trauma counselling. This counselling helped me clear my mind. Before I felt like a mad person. I hated everybody, I could not approach anybody. All of the symptoms of trauma that they enumerated were mine. I felt that I was not a human being at all. I felt like I was stupid. After the training, I found myself able to speak. Bit by bit I regained my intelligence. 
My trauma decreased and my deep thinking disappeared. The fire I felt in my heart has also gone. But I still have physical injuries.

I met one of the men who had raped me after the genocide. After meeting him, and long before Gacaca started, I went to the prosecutor's office in order to denounce him. I told them how he had murdered and raped people, but did not speak about my own rape. They imprisoned him for a few days, after which they released him. What made me sad at that time was that the prosecutor's lawyer considered me a mad woman. The fact that she refused to listen to me caused me troubled thoughts.

Later on, when Gacaca started, I participated like others. I felt upset about the rapist who had not been prosecuted, so at the beginning of the Gacaca court proceedings I approached one lady, who was a Gacaca judge, but she did not help me in any way. I told my story for the first time to that lady judge, but after telling her my story I regretted it, because there was no outcome. Instead, I felt the fire in my heart and that I had no security. I had planned to denounce the people who had stolen from my house and those who had slaughtered my relatives, because I know them. But then, after observing how the Interahamwe denied what they had done during the genocide, I felt that to denounce them would not bring anything to me. I found it useless because they would not bring my life back or my looted properties.

Since then, I felt that I am supposed to keep all things I have in my heart. Thereafter I never showed others my problems; I kept them in my heart. When the general prosecutor's office brought up rape issues in Gacaca, I noticed that the judges did not consider our sufferings. I became discouraged. It would have been better if it had remained the task of the national courts.
Even though I used to lock myself in my room and cry when I was feeling sorrowful, my friends were aware of my sufferings. Therefore, one of my friends invited me to join sociotherapy, which helped me so much. After joining sociotherapy, I told my problem to a white lady. Before sharing my story with her, I was afraid and ashamed. While speaking, I had a kind of intense sadness and I was remembering what had happened. After speaking, I went back to regretting. But I no longer feel regret because she was generous to us. She continued to be near us. The first time I learned about sociotherapy, I joined a group with different kinds of people. But I did not share my story in that group because I did not want to expose myself. From this first group, I learnt that I was preventing my children and neighbours from having security. I was always irritated and often insulted them. As I was not yet healed, I later joined a second sociotherapy group with only women genocide survivors.

When I was invited to join the second group, I thought that they wanted to get information from me. Coming there, I met people who wanted to listen to others. Before joining sociotherapy, I was living in isolation. Even if I had been counselled by Kanyarwanda, Gacaca affected me so much. Most of the time, I was feeling like I was not a human being, I felt diminished. Whenever I went to seek a service, I would look down, hide my face. I thought that I was giving off a bad smell to others. Flies used to follow me. I felt that I was not clean. In reality, I was afraid of speaking, because I thought that I could not say anything meaningful. I prevented my children from having safety. I transferred the badness that the Interahamwe had done to me on to them. Before, I was always saying that it would not get dark after it gets light, or not light after it gets dark. I 
had no hope. I was always tormenting my child born from rape through insults. After joining sociotherapy, the people I met there helped me to become a human being again. They gave me their time and they listened to me. They understood my suffering and they did not stigmatize me. The step of safety was especially useful for me.

In this group, I only shared how I had survived the genocide and the loss of my relatives. After speaking, my grief reduced. I now have trust. My headaches have reduced. I stopped the medicines I was taking from the neuropsychiatric hospital of Ndera. After going through sociotherapy, I accepted my daughter born from rape and I became aware that I am still alive.

When other women were sharing their stories of rape in sociotherapy, I realised that there were other people who had the same problems as mine. Their discussions took me out of my shame. We had good moments together. We cried freely as if nobody was looking at us. We were the same. These moments reminded me of how we had been abused and how Hutus had deprived us of our value. Before, I was frittering away money. I did not have a plan for my life. But today, I am thinking about my future instead of thinking about my past.

Because I learnt how to have safety and how to provide that safety to others, I gave my family and my neighbours the security I had deprived them of. I live peacefully with everybody, which is different from before. I can be patient when someone insults me. Before, I was always fighting and insulting them in return. I was always beating my children because of my anger. Now, I no longer beat them. I teach them to work instead of beating them. I noticed that I wanted them to think and behave like mature people, even though they are children and they behave like children. From sociotherapy,
I got life back in my thoughts, but I have no physical life; I am always sick.

I am thankful to God that I am not HIV positive like my fellow women who have been raped. Yet I do not have a living. The life of my children makes me worry. They are still young, they cannot feed themselves. My husband is traumatized, he doesn't have any thoughts. This started a few years after the genocide. I think that he is more traumatized than I am. That explains his bad behaviour towards me and the children. My house and the whole family are resting on my shoulders. Because of my lack of a living I live with ihahamuka. When I see that my child is not attending a good school, I feel traumatized because I do not have anything else to do for them.

I wish to live in a good place, but I do not have anywhere to start from. I have no job and I cannot find one, because people are afraid of my scars. They say that I am unable to work; I am seen as a handicapped person. I still need a doctor who can treat my scars, because I feel pain. I have an infection in my body due to the machetes. The medicine I took did not have any positive effect. I need to be treated by an expert for my infection and the cancer in my jaw. Because I am looking at the future now, I want to be healthy in my thoughts and in my body, in order to work hard and feed my family properly. I expect good things, like getting out of poverty.

I noticed that sociotherapy is a medicine. However, I regret not speaking about the rape when I was attending sociotherapy sessions. If I was invited to a third group I would speak about the rape. I do not want to keep it silent. Therefore, I would advise other women to be patient and talk about the rape they have faced, because there is a treatment in talking about this bad experience. All women who have been raped should not feel 
guilty, because they did not choose to be raped. Thus, they do not have to be ashamed of talking. I advise them also to disclose this problem to anybody who can listen to them. 